Case Report

\title{
Acute Aneurismal Bilateral Subdural Haematoma without Subarachnoid Haemorrhage: A Case Report and Review of the Literature
}

\author{
Ossama Mansour, ${ }^{1}$ Tamer Hassen, ${ }^{2}$ and Sameh Fathy ${ }^{3}$ \\ ${ }^{1}$ Neurology and Endovascular Neurology Department, Alexandria University Hospital, Champlion Street, Alazareeta, \\ Medical Campus, Alexandria 23169, Egypt \\ ${ }^{2}$ Neurosurgery Department, Alexandria University Hospital, Champlion Street, Alazareeta, Medical Campus, Alexandria 23169, Egypt \\ ${ }^{3}$ Radiodiagnosis Department, Zagazig University Hospital, Zagazig 24533, Egypt
}

Correspondence should be addressed to Ossama Mansour; yassinossama@yahoo.com

Received 7 February 2014; Revised 17 May 2014; Accepted 19 May 2014; Published 18 June 2014

Academic Editor: José Luis González-Gutiérrez

Copyright (C) 2014 Ossama Mansour et al. This is an open access article distributed under the Creative Commons Attribution License, which permits unrestricted use, distribution, and reproduction in any medium, provided the original work is properly cited.

Spontaneous pure acute bilateral subdural haematoma (ASDH) without intraparenchymal or subarachnoid haemorrhage caused by a ruptured cerebral aneurysm is extremely rare. It can follow rupture of different aneurysms specially located in anterior incisural space; the most frequently encountered location is the PcoA aneurysms as demonstrated in the present case. We present a case report of a PcoA aneurysm presenting as pure bilateral ASDH. A high level of suspicion for bleeding of arterial origin should be maintained in all cases of acute subdural haematoma without history of trauma. The neurological status on admission dictates the appropriate timing and methodology of the neuroradiological investigations.

\section{Introduction}

In the majority of cases, acute subdural haematomas (ASDHs) are related to head trauma and are typically caused by disruption of superficial cerebral or cortical bridging veins. Spontaneous ASDHs are uncommonly encountered. Arteriovenous malformations [1], cocaine abuse [1], and many other causes have been proposed for this pathology [2] Hemorrhage of aneurysms often presents as subarachnoid haemorrhage $(\mathrm{SAH})$ and intracerebral haemorrhage (ICH); the ASDH is rare. ASDHs constitute neurosurgical emergencies and immediate treatment must be conducted before neurological deficits become irreversible.

We report a case of a spontaneous bilateral pure ASDH due to rupture of an aneurysm of the left posterior communicating aneurysm $(\mathrm{PcoA})$ with reviewing of literature.

\section{Case Report}

A 51-year-old controlled diabetic and hypertensive man presented with a history of sudden onset of headache followed by reduction of the level of consciousness $(\mathrm{GSC}=7$ ) and right anisocoria, which could be old or just "false, localizing sign." There was no history of trauma or previous neurological disease. CT scan revealed a bilateral high density subdural haematoma at the brain convexity without significant mass effect, SAH, or ICH (intracerebral hemorrhage); MRI confirmed the CT diagnosis (Figure 1). On admission, patient was somnolent and disoriented. There was no evidence of head injury and general physical examination was unremarkable. On admission, haemoglobin was $9 \mathrm{~g} / \mathrm{dL}$; other laboratory data including a coagulopathy screen and CSF analysis were normal.

Owing to rapid clinical deterioration, he was intubated and taken to the operating room. Emergency bilateral frontotemporal craniotomy was performed and haematoma evacuated. There were neither signs of damaged underlying cortex nor typical signs of SAH on the surface. A bleeding cortical artery or other abnormalities could not be identified. On the first postoperative day, he recovered consciousness and was able to follow commands and to move all extremities. Because of the spontaneous course of the ASDH, he underwent 


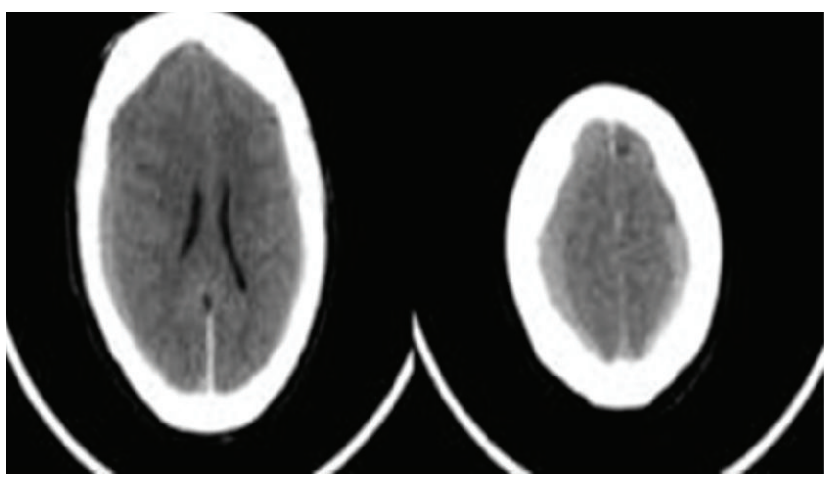

(a)

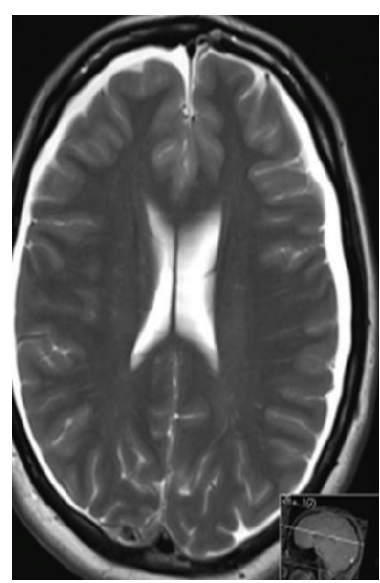

(b)

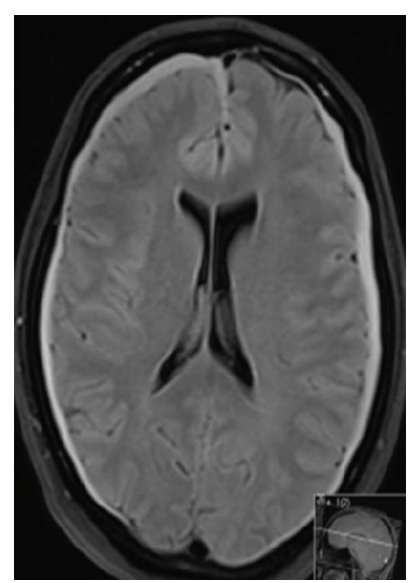

(c)

FIGURE 1: (a) Noncontrast head CT: bilateral hematomas are present. These are predominantly isodense to slightly hypodense compared to the adjacent gray matter (29-35 Hounsfield units), which could be explained by anemia (hemoglobin was 9 g/dL). (b) and (c) Bilateral subdural hematomas, confirmed as shown in both MRI T2 and FLAIR sequences.

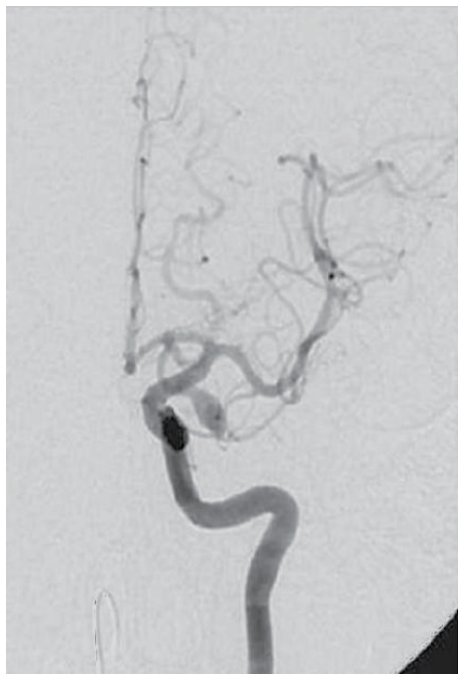

(a)

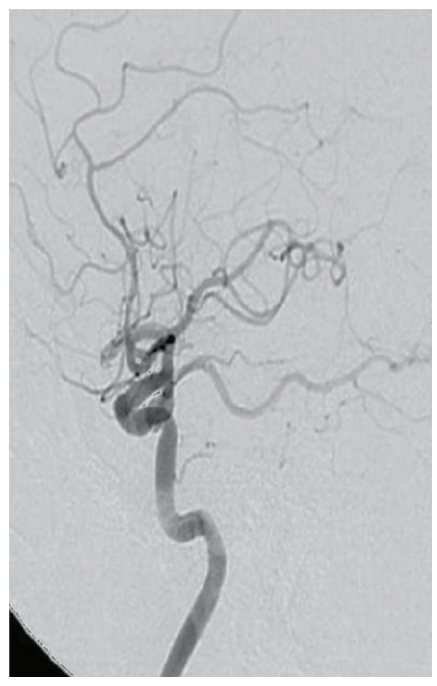

(b)

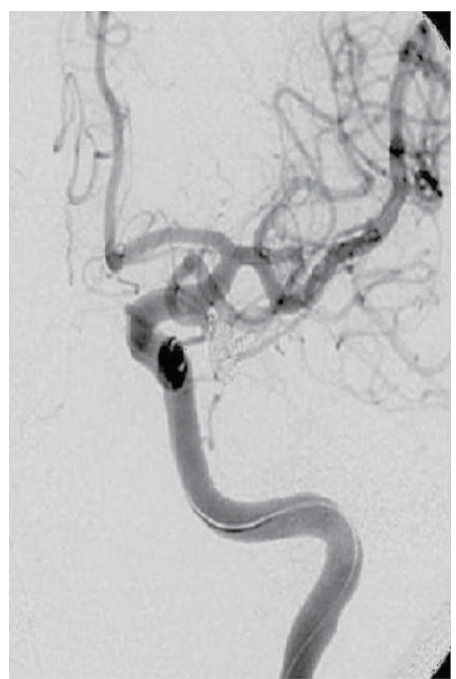

(c)

FIGURE 2: Left internal carotid DSA: AP (a) and lateral views, (b) demonstrating aneurysm of left PCoA, (c) AP view after embolisation (coils) showing complete obliteration of the aneurysm.

cerebral angiography. This revealed a left saccular PCoA aneurysm $(4.5 * 7.5 \mathrm{~mm})$ (Figures $2(\mathrm{a})$ and $2(\mathrm{~b}))$. AP-view angiography showed an irregular shape of the aneurysm with additional small outpouching indicating possible point of rupture at the inflow zone (Figures 2 (a) and 2(b)). The patient underwent successful coiling of the aneurysm (Figure 2(c)). His following hospital stay was uneventful, and he was discharged on the 11th postoperative day without neurological deficits, being able to return to his normal life.

\section{Discussion}

ASDHs develop spontaneously in patients without history of trauma or coagulopathy and an aneurysm rupture is responsible for the majority of such cases with incidence of about $0.5 \%$ to $7.9 \%$ [3-6].

Several mechanisms have been proposed to explain the occurrence of ASDH after aneurysm rupture. Firstly, successive minor sentinel haemorrhages may fix an aneurysm to local arachnoid adhesions (Figure 3) resulting in bleeding directly into the subdural space when an arachnoid tear occurs after aneurysmal rupture or simply through a weak point at the arachnoid membrane without previous sentinel bleeding [6]. A second mechanism may be due to a haemorrhage under high pressure, leading to pia-arachnoid rupture and extravasation of blood into the subdural space, where in this scenario the subdural hematoma may develop secondary to the compensatory decompression of an intracerebral 

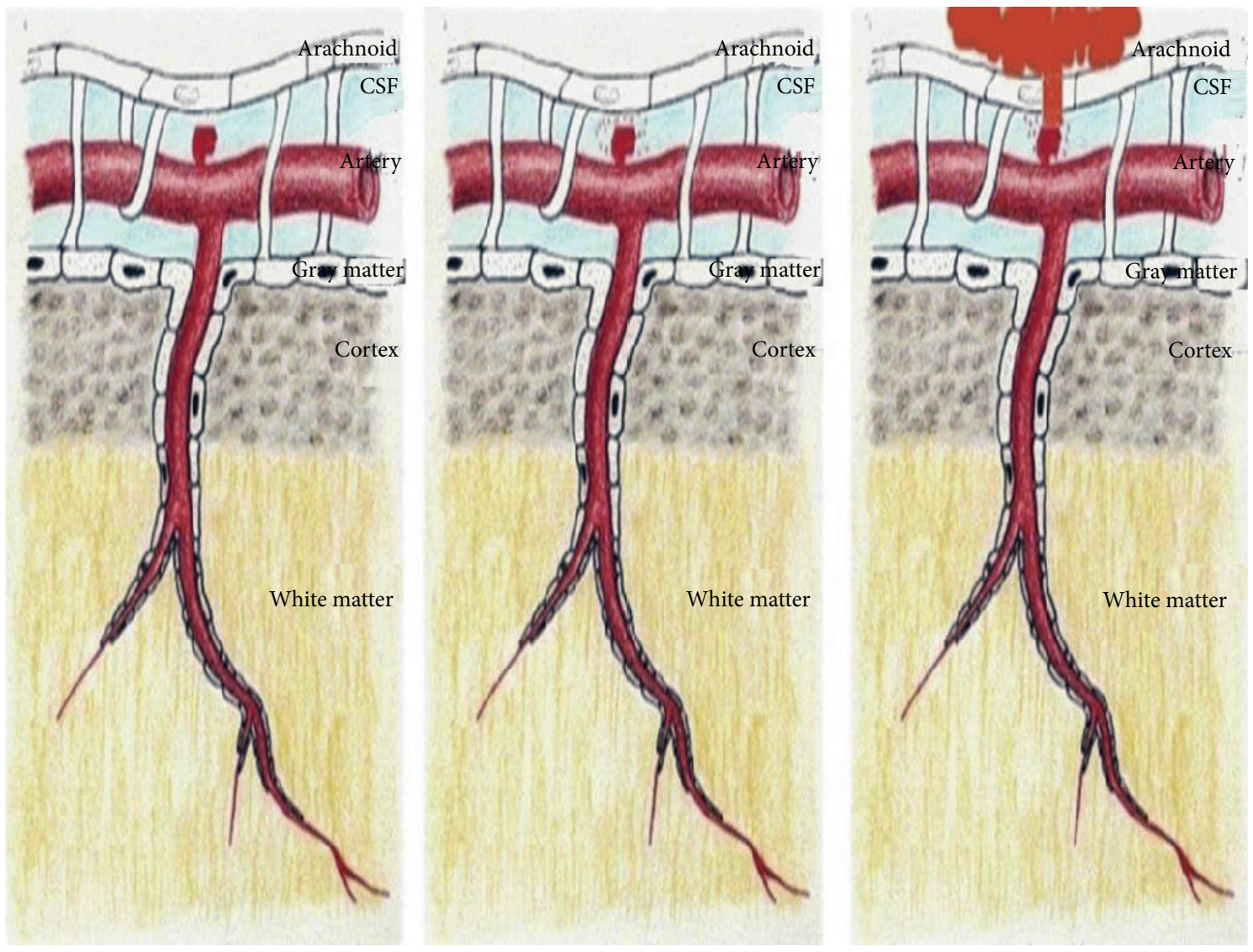

FIGURE 3: Diagram illustrating the different stages that possibly make an aneurysm bleed in subdural space.

hematoma into the subdural space following disruption of the arachnoid covering the cerebral cortex [6].

Biesbroek et al. reported retrospectively on 1757 ruptured aneurysms where 63 cases had an ASDH (as a presenting manifestation). Increasing age, sentinel headache, $\mathrm{ICH}$, and aneurysms at the PCoA were independent risk factors for ASDH. Patients with a basilar or vertebral aneurysm have a low risk for ASDH [4]. The incidence of pure ASDH, without associated ICH or SAH, due to a ruptured aneurysm is extremely rare. The reported cases in literature are summarized in Table 1. The most frequent site of aneurysm causing pure $\mathrm{ASDH}$ was at the origin of the $\mathrm{PCoA}$ from the internal carotid artery (IC-PC) (60\% of the cases), followed by the distal anterior cerebral artery (ACA) (16\%) and middle cerebral artery $(12 \%)$.

In the present case, the bilateral ASDH due to a PCoA aneurysm presented as pure bilateral ASDH. Anatomically, the anterior incisural space, which is located anterior to brainstem, contains the posterior communicating artery (PCoA), anterior choroidal artery, and basilar bifurcation; additionally, it contains the supraclinoidal portion of the internal carotid artery [4]. This space opens laterally into the part of the Sylvian fissure situated below the anterior perforated substance [4]. This explains the occurrence of a subdural haematoma following aneurysm rupture arising from arteries located in this space like PCoA aneurysm as in the present case, where blood finds its way through the abovementioned pathway to the subdural spaces.

Pure ASDH following rupture of intracranial aneurysm carried a poor prognosis in 34.3\% (12 of 357; 14.3\% disabled and $22.8 \%$ died due to bleeding) of the reported cases in literature. The $22.8 \%$ mortality rate in this group of patients is slightly higher than the mortality rate of simple traumatic subdural haematomas (reported to be 20\%) [4]. The simple traumatic ASDHs are distinguished from the complicated traumatic subdural haematomas by the absence of parenchymal damage [4]. This assumed that the difference in mortality rate may be due to the initial elevated intracranial pressure caused by the subdural haematoma or by rebleeding of the aneurysm before its occlusion. Therefore, adequate diagnostic investigations and respective prompt treatment are essential for a better outcome. If the patient presents with a stable neurological condition, angiography should be performed prior to surgery to dictate the best strategy. In the presence of a definite bleeding source, emergency surgery should be adopted to evacuate the haematoma and operate on the bleeding source.

If the angiography does not demonstrate the source of bleeding, the patient can be managed conservatively or surgically according to the subsequent evolution of the neurological status. In cases of patients presenting with rapid neurological deterioration, immediate decompression 
TABLE 1: Cases of pure subdural haematoma (without subarachnoid haemorrhage and without intraparenchymal haematoma) caused by rupture of intracranial aneurysm $[5,6]$.

\begin{tabular}{|c|c|c|c|c|c|c|c|c|}
\hline Case & Author & $\begin{array}{l}\text { Age } \\
\text { (years) }\end{array}$ & Sex & Symptoms/signs & $\begin{array}{l}\text { Location of } \\
\text { aneurysm }\end{array}$ & $\begin{array}{c}\text { Location of } \\
\text { subdural } \\
\text { haematoma }\end{array}$ & Treatment & Outcome \\
\hline 1 & $\begin{array}{l}\text { Rengachary et al. } \\
\text { (1981) [7] }\end{array}$ & 49 & M & $\begin{array}{l}\text { Confusion and } \\
\text { dysphasia }\end{array}$ & $\begin{array}{l}\text { Sylvian branch } \\
\text { of MCA }\end{array}$ & Convexity & $\begin{array}{c}\text { Haematoma evacuation } \\
\text { and clipping }\end{array}$ & Good \\
\hline 2 & $\begin{array}{c}\text { Eggers et al. (1982) } \\
{[8]}\end{array}$ & 34 & $\mathrm{~F}$ & Headache & IC- PC & Convexity & Haematoma evacuation & Good \\
\hline 3 & $\begin{array}{l}\text { Williams et al. } \\
\text { (1983) [9] }\end{array}$ & 18 & $\mathrm{~F}$ & Coma & IC-PC & Convexity & $\begin{array}{c}\text { Haematoma evacuation } \\
\text { and clipping }\end{array}$ & Disabled \\
\hline 4 & $\begin{array}{l}\text { Friedman et al. } \\
\text { (1983) [10] }\end{array}$ & 55 & $\mathrm{~F}$ & Headache & IC-PC & $\begin{array}{l}\text { Tentorium and } \\
\text { interhemispheric }\end{array}$ & Clipping & Good \\
\hline 5 & $\begin{array}{l}\text { O’Leary et al. } \\
\text { (1986) [11] }\end{array}$ & 28 & $\mathrm{~F}$ & Coma & MCA & Convexity & None & Dead \\
\hline 6 & $\begin{array}{l}\text { Kondziolka et al. } \\
\quad(1988)[12]\end{array}$ & 43 & M & Coma & IC-PC & $\begin{array}{l}\text { Tentorium and } \\
\text { convexity }\end{array}$ & $\begin{array}{c}\text { Haematoma evacuation } \\
\text { and clipping }\end{array}$ & Good \\
\hline 7 & $\begin{array}{l}\text { Kondziolka et al. } \\
\text { (1988) [12] }\end{array}$ & 38 & $\mathrm{~F}$ & Coma & IC-PC & $\begin{array}{l}\text { Tentorium and } \\
\text { convexity }\end{array}$ & $\begin{array}{l}\text { Haematoma evacuation } \\
\text { and clipping }\end{array}$ & Disabled \\
\hline 8 & $\begin{array}{l}\text { Shinmura et al. } \\
\text { (1989) [13] }\end{array}$ & 44 & $\mathrm{~F}$ & Coma & MCA & Convexity & $\begin{array}{c}\text { Haematoma evacuation } \\
\text { and clipping }\end{array}$ & Disabled \\
\hline 9 & $\begin{array}{l}\text { Onda et al. (1989) } \\
\text { [14] }\end{array}$ & 51 & $\mathrm{~F}$ & Semicoma & IC-PC & Convexity & $\begin{array}{l}\text { Haematoma evacuation } \\
\text { and clipping }\end{array}$ & Disabled \\
\hline 10 & $\begin{array}{l}\text { Watanabe et al. } \\
\text { (1991) [15] }\end{array}$ & 27 & M & Semicoma & Distal ACA & $\begin{array}{l}\text { Interhemispheric } \\
\text { and convexity }\end{array}$ & $\begin{array}{c}\text { Haematoma evacuation } \\
\text { and clipping }\end{array}$ & Dead \\
\hline 11 & $\begin{array}{l}\text { Ragland et al. } \\
\text { (1993) [16] }\end{array}$ & 55 & M & Coma & AcomA & Convexity & Haematoma evacuation & Dead \\
\hline 12 & $\begin{array}{l}\text { Hatayama et al. } \\
\text { (1994) [17] }\end{array}$ & 55 & M & Semicoma & Distal ACA & $\begin{array}{l}\text { Interhemispheric } \\
\text { and convexity }\end{array}$ & $\begin{array}{l}\text { Haematoma evacuation } \\
\text { and clipping }\end{array}$ & Good \\
\hline 13 & $\begin{array}{l}\text { Hatayama et al. } \\
\text { (1994) [17] }\end{array}$ & 66 & $\mathrm{~F}$ & Semicoma & Distal ACA & $\begin{array}{l}\text { Interhemispheric, } \\
\text { convexity, and } \\
\text { tentorium }\end{array}$ & $\begin{array}{l}\text { Haematoma evacuation } \\
\text { and clipping }\end{array}$ & Disabled \\
\hline 14 & $\begin{array}{l}\text { Ishibashi et al. } \\
\text { (1997) [18] }\end{array}$ & 54 & $\mathrm{~F}$ & Headache & IC & $\begin{array}{c}\text { Tentorium and } \\
\text { convexity }\end{array}$ & $\begin{array}{l}\text { Haematoma evacuation } \\
\text { and clipping }\end{array}$ & Good \\
\hline 15 & $\begin{array}{c}\text { Satoh et al. (1999) } \\
\text { [19] }\end{array}$ & 58 & $\mathrm{~F}$ & Semicoma & IC & Convexity & $\begin{array}{c}\text { Haematoma evacuation } \\
\text { and clipping }\end{array}$ & Good \\
\hline 16 & $\begin{array}{c}\text { Satoh et al. (1999) } \\
\text { [19] }\end{array}$ & 25 & $\mathrm{~F}$ & Headache & IC & Convexity & $\begin{array}{c}\text { Haematoma evacuation } \\
\text { and clipping }\end{array}$ & Good \\
\hline 17 & $\begin{array}{c}\text { Satoh et al. (1999) } \\
\text { [19] }\end{array}$ & 22 & $\mathrm{~F}$ & Coma & IC & Convexity & $\begin{array}{l}\text { Haematoma evacuation } \\
\text { and clipping }\end{array}$ & Good \\
\hline 18 & $\begin{array}{l}\text { Nonaka et al. } \\
(2000)[20]\end{array}$ & 52 & $\mathrm{~F}$ & Coma & IC & $\begin{array}{l}\text { Tentorium and } \\
\text { convexity }\end{array}$ & $\begin{array}{c}\text { Haematoma evacuation } \\
\text { and clipping }\end{array}$ & Good \\
\hline 19 & $\begin{array}{l}\text { Ishikawa et al. } \\
\text { (2000) [21] }\end{array}$ & 62 & M & $\begin{array}{l}\text { Headache and } \\
\text { ptosis }\end{array}$ & IC & $\begin{array}{l}\text { Tentorium and } \\
\text { interhemispheric }\end{array}$ & Clipping & Good \\
\hline 20 & $\begin{array}{l}\text { Inamasu et al. } \\
(2002)[22]\end{array}$ & 28 & $\mathrm{~F}$ & Coma & IC & Convexity & Haematoma evacuation & Dead \\
\hline 21 & $\begin{array}{c}\text { Araki et al. (2002) } \\
\text { [23] }\end{array}$ & 55 & $\mathrm{~F}$ & $\begin{array}{l}\text { Headache, ptosis, } \\
\text { and semicoma }\end{array}$ & IC & Convexity & $\begin{array}{c}\text { Haematoma evacuation } \\
\text { and clipping }\end{array}$ & Good \\
\hline 22 & $\begin{array}{c}\text { Blake et al. (2003) } \\
\text { [24] }\end{array}$ & 35 & $\mathrm{~F}$ & Coma & IC & Convexity & Non & Dead \\
\hline 23 & $\begin{array}{l}\text { Katsuno et al. } \\
\text { (2003) [25] }\end{array}$ & 62 & $\mathrm{~F}$ & $\begin{array}{l}\text { Headache, nausea, } \\
\text { and dizziness }\end{array}$ & Distal ACA & $\begin{array}{l}\text { Interhemispheric } \\
\text { and convexity }\end{array}$ & $\begin{array}{c}\text { Haematoma evacuation } \\
\text { and clipping }\end{array}$ & Good \\
\hline 24 & $\begin{array}{l}\text { Shenoy et al. } \\
\text { (2003) [26] }\end{array}$ & 45 & $\mathrm{~F}$ & $\begin{array}{l}\text { Headache and } \\
\text { blurring of vision }\end{array}$ & MCA & Convexity & $\begin{array}{c}\text { Haematoma evacuation } \\
\text { and clipping }\end{array}$ & Good \\
\hline 25 & $\begin{array}{l}\text { Shenoy et al. } \\
\text { (2003) [26] }\end{array}$ & & $\mathrm{F}$ & $\begin{array}{l}\text { Semicoma and } \\
\text { hemiparesis }\end{array}$ & IC-PC & Convexity & $\begin{array}{l}\text { Haematoma evacuation } \\
\text { and clipping }\end{array}$ & Good \\
\hline
\end{tabular}


TABle 1: Continued.

\begin{tabular}{|c|c|c|c|c|c|c|c|c|}
\hline Case & Author & $\begin{array}{l}\text { Age } \\
\text { (years) }\end{array}$ & Sex & Symptoms/signs & $\begin{array}{l}\text { Location of } \\
\text { aneurysm }\end{array}$ & $\begin{array}{c}\text { Location of } \\
\text { subdural } \\
\text { haematoma }\end{array}$ & Treatment & Outcome \\
\hline 26 & $\begin{array}{l}\text { Koerbe et al. } \\
(2005) \text { [27] }\end{array}$ & 63 & $\mathrm{~F}$ & $\begin{array}{l}\text { Headache and } \\
\text { semicoma }\end{array}$ & $\begin{array}{l}\text { Bifurcation of } \\
\text { ICA }\end{array}$ & Convexity & $\begin{array}{c}\text { Hematoma evacuation } \\
\text { and coiling }\end{array}$ & Good \\
\hline 27 & $\begin{array}{l}\text { Boujemâa et al. } \\
\text { (2006) [28] }\end{array}$ & 44 & $\mathrm{~F}$ & Coma & IC-PC & $\begin{array}{c}\text { Bilateral convexity } \\
\text { and a hyperdensity } \\
\text { on the tentorium } \\
\text { cerebelli }\end{array}$ & $\begin{array}{c}\text { Hematoma evacuation } \\
\text { and coiling }\end{array}$ & Dead \\
\hline 28 & $\begin{array}{c}\text { Gilad et al. (2007) } \\
\text { [29] }\end{array}$ & 47 & $\mathrm{M}$ & $\begin{array}{l}\text { Nausea and } \\
\text { vomiting }\end{array}$ & AcomA & $\begin{array}{l}\text { Sella, migrating to } \\
\text { spinal canal }\end{array}$ & Coiling & Good \\
\hline 29 & $\begin{array}{c}\text { Kocak et al. (2009) } \\
{[30]}\end{array}$ & 47 & $\mathrm{~F}$ & Not described & AcomA & Not described & Clipping & Good \\
\hline 30 & $\begin{array}{l}\text { Weil et al. (2010) } \\
\text { [31] }\end{array}$ & 51 & $\mathrm{~F}$ & Coma & MCA & Convexity & $\begin{array}{c}\text { Haematoma } \\
\text { evacuation and coiling }\end{array}$ & Dead \\
\hline 31 & $\begin{array}{l}\text { De Blasi et al. } \\
\text { (2010) [32] }\end{array}$ & 47 & $\mathrm{~F}$ & $\begin{array}{l}\text { Headache and } \\
\text { stupor }\end{array}$ & ICA-PcomA & Convexity & Coiling & Good \\
\hline 32 & $\begin{array}{l}\text { De Blasi et al. } \\
\text { (2010) [32] }\end{array}$ & 60 & $\mathrm{~F}$ & $\begin{array}{l}\text { Headache and } \\
\text { abducens palsy }\end{array}$ & MCA & Convexity & Clipping & Good \\
\hline 33 & Takada (2012) [33] & 54 & M & Headache & AcomA & $\begin{array}{l}\text { Tentorium and } \\
\text { convexity }\end{array}$ & Clipping & Good \\
\hline 34 & Mrfka (2012) [6] & 40 & $\mathrm{~F}$ & $\begin{array}{l}\text { Headache, nausea, } \\
\text { and vomiting }\end{array}$ & PcomA & Convexity & $\begin{array}{c}\text { Haematoma } \\
\text { evacuation and coiling }\end{array}$ & Good \\
\hline 35 & Jie Gong (2014) [5] & 43 & M & Headache & $\mathrm{MCA}$ & Convexity & $\begin{array}{c}\text { Haematoma evacuation } \\
\text { and resection }\end{array}$ & Good \\
\hline
\end{tabular}

surgery should be performed before performing angiography. In the absence of intraoperative identification of a cortical arterial rupture or other source of bleeding, complementary postoperative arteriography is required, to rule out sources which could not be detected during surgical evacuation.

In summary, a high level of suspicion for bleeding of arterial origin should be maintained in all cases of ASDH without history of trauma which may mandate vascular assessment as routine.

\section{Conflict of Interests}

The authors declare that there is no conflict of interests regarding the publication of this paper.

\section{References}

[1] Ó. L. Alves and Ó. Gomes, "Cocaine-related acute subdural hematoma: an emergent cause of cerebrovascular accident," Acta Neurochirurgica, vol. 142, no. 7, pp. 819-821, 2000.

[2] B. Depreitere, F. Van Calenbergh, and J. van Loon, "A clinical comparison of non-traumatic acute subdural haematomas either related to coagulopathy or of arterial origin without coagulopathy," Acta Neurochirurgica, vol. 145, no. 7, pp. 541-546, 2003.

[3] W.-S. Cho, B. Batchuluun, S. J. Lee, H.-S. Kang, and J. E. Kim, "Recurrent subdural hematoma from a pseudoaneurysm at the cortical branch of the middle cerebral artery after mild head injury: case report," Neurologia Medico-Chirurgica, vol. 51, no. 3, pp. 217-221, 2011.
[4] J. M. Biesbroek, G. J. E. Rinkel, A. Algra, and J. W. B. van der Sprenkel, "Risk factors for acute subdural hematoma from intracranial aneurysm rupture," Neurosurgery, vol. 71, no. 2, pp. 264-268, 2012.

[5] J. Gong, H. Sun, X. Y. Shi, W. X. Liu, and Z. Shen, "Pure subdural haematoma caused by rupture of middle cerebral artery aneurysm: case report and literature review," The Journal of International Medical Research, vol. 42, no. 3, pp. 870-878, 2014.

[6] M. Mrfka, K. Pistracher, M. Augustin, S. Kurschel-Lackner, and M. Mokry, "Acute subdural hematoma without subarachnoid hemorrhage or intraparenchymal hematoma caused by rupture of a posterior communicating artery aneurysm: case report and review of the literature," Journal of Emergency Medicine, vol. 44, no. 6, pp. e369-e373, 2013.

[7] S. S. Rengachary and D. C. Szymanski, "Subdural hematomas of arterial origin,” Neurosurgery, vol. 8, no. 2, pp. 166-172, 1981.

[8] F. M. Eggers, T. A. Tomsick, R. R. Lukin, and A. A. Chambers, "Recognition of subdural hematoma secondary to ruptured aneurysm by computerized tomography," Computerized Radiology, vol. 6, no. 5, pp. 309-313, 1982.

[9] J. P. Williams, J. N. Joslyn, J. L. White, and D. F. Dean, "Subdural hematoma secondary to ruptured intracranial aneurysm: computed tomographic diagnosis," Journal of Computed Tomography, vol. 7, no. 2, pp. 149-153, 1983.

[10] M. B. Friedman and M. Brant Zawadzki, "Interhemispheric subdural hematoma from ruptured aneurysm," Computerized Radiology, vol. 7, no. 2, pp. 129-134, 1983.

[11] P. M. O'Leary and P. J. Sweeny, "Ruptured intracerebral aneurysm resulting in a subdural hematoma," Annals of Emergency Medicine, vol. 15, no. 8, pp. 944-946, 1986. 
[12] D. Kondziolka, M. Bernstein, K. Ter Brugge, and H. Schutz, "Acute subdural hematoma from ruptured posterior communicating artery aneurysm," Neurosurgery, vol. 22, no. 1, pp. 151-154, 1988.

[13] F. Shinmura, S. Nakajima, T. Maruyama, and S. Azuma, "A case of ruptured middle cerebral artery aneurysm with acute subdural hematoma after clipping of the aneurysm nine years previously," Neurological Surgery, vol. 17, no. 12, pp. 1175-1179, 1989 (Japanese).

[14] J. Onda, Y. Kodama, K. Emoto, and K. Yuki, "A case report of "pure" acute subdural hematoma secondary to ruptured intracranial aneurysm," Kyukyu Igaku, vol. 13, pp. 631-634, 1989 (Japanese).

[15] K. Watanabe, S. Wakai, S. Okuhata, and M. Nagai, "Ruptured distal anterior cerebral artery aneurysms presenting as acute subdural hematoma. Report of three cases," Neurologia MedicoChirurgica, vol. 31, no. 8, pp. 514-517, 1991.

[16] R. L. Ragland, N. D. Gelber, H. A. Wilkinson, J. R. Knorr, and A. A. Tran, "Anterior communicating artery aneurysm rupture: an unusual cause of acute subdural hemorrhage," Surgical Neurology, vol. 40, no. 5, pp. 400-402, 1993.

[17] T. Hatayama, T. Shima, Y. Okada et al., "Ruptured distal anterior cerebral artery aneurysms presenting with acute subdural hematoma: report of two cases," No Shinkei Geka, vol. 22, no. 6, pp. 577-582, 1994 (Japanese).

[18] A. Ishibashi, Y. Yokokura, and M. Sakamoto, "Acute subdural hematoma without subarachnoid hemorrhage due to ruptured intracranial aneurysm," Neurologia Medico-Chirurgica, vol. 37, no. 7, pp. 533-537, 1997.

[19] K. Satoh, T. Sasaki, T. Osato et al., "Intracranial aneurysm presenting as acute subdural hematoma without subarachnoid hemorrhage: report of three cases," Journal of the Hokkaido Brain Research Foundation, vol. 8, pp. 27-31, 1999.

[20] Y. Nonaka, M. Kusumoto, K. Mori, and M. Maeda, "Pure acute subdural haematoma without subarachnoid haemorrhage caused by rupture of internal carotid artery aneurysm," Acta Neurochirurgica, vol. 142, no. 8, pp. 941-944, 2000.

[21] E. Ishikawa, K. Sugimoto, K. Yanaka et al., "Interhemispheric subdural hematoma caused by a ruptured internal carotid artery aneurysm: case report," Surgical Neurology, vol. 54, no. 1, pp. 82$86,2000$.

[22] J. Inamasu, R. Saito, Y. Nakamura et al., "Acute subdural hematoma caused by ruptured cerebral aneurysms: diagnostic and therapeutic pitfalls," Resuscitation, vol. 52, no. 1, pp. 71-76, 2002.

[23] T. Araki, T. Sampei, H. Murata, H. Fujiwara, and W. Taki, "A case of internal carotid-posterior communicating artery aneurysm presenting pure acute subdural hematoma," No Shinkei Geka, vol. 30, no. 8, pp. 861-866, 2002 (Japanese).

[24] G. Blake, M. James, C. Ramjit, G. Char, R. Hunter, and I. Crandon, "Acute subdural haematoma without subarachnoid haemorrhage caused by rupture of an intracranial aneurysm," West Indian Medical Journal, vol. 52, no. 1, pp. 80-81, 2003 (Japanese).

[25] M. Katsuno, Y. Murai, and A. Teramoto, "Acute subdural hematoma without subarachnoid hemorrhage following rupture of a distal anterior cerebral artery aneurysm: a case report," No To Shinkei, vol. 55, no. 5, pp. 435-438, 2003 (Japanese).

[26] S. N. Shenoy, M. G. Kumar, and A. Raja, "Intracranial aneurysms causing spontaneous acute subdural hematoma," Neurology India, vol. 51, no. 3, pp. 422-424, 2003.
[27] A. Koerbel, U. Ernemann, and D. Freudenstein, "Acute subdural haematoma without subarachnoid haemorrhage caused by rupture of an internal carotid artery bifurcation aneurysm: case report and review of literature," The British Journal of Radiology, vol. 78, no. 931, pp. 646-650, 2005.

[28] H. Boujemâa, F. Góngora-Rivera, H. Barragán-Campos, K. Karachi, J. Chiras, and N. Sourour, "Bilateral acute subdural hematoma from ruptured posterior communicating artery aneurysm. A case report," Interventional Neuroradiology, vol. 12, no. 1, pp. 37-40, 2006.

[29] R. Gilad, G. M. Fatterpekar, D. M. Johnson, and A. B. Patel, "Migrating subdural hematoma without subarachnoid hemorrhage in the case of a patient with a ruptured aneurysm in the intrasellar anterior communicating artery," American Journal of Neuroradiology, vol. 28, no. 10, pp. 2014-2016, 2007.

[30] A. Kocak, O. Ates, A. Durak, A. Alkan, S. Cayli, and K. Sarac, "Acute subdural hematomas caused by ruptured aneurysms: experience from a single Turkish center," Turkish Neurosurgery, vol. 19, no. 4, pp. 333-337, 2009.

[31] A. G. Weil, N. McLaughlin, P. Lessard-Bonaventure, and M. W. Bojanowski, "A misleading distal anterior cerebral artery aneurysm," Surgical Neurology International, vol. 1, article 55, 2010.

[32] R. De Blasi, A. Salvati, M. Renna, and L. Chiumarulo, "Pure subdural hematoma due to cerebral aneurysmal rupture: an often delayed diagnosis," CardioVascular and Interventional Radiology, vol. 33, no. 4, pp. 870-873, 2010.

[33] T. Takada, T. Yamamoto, E. Ishikawa et al., "Acute subdural hematoma without subarachnoid hemorrhage caused by ruptured A1-A2 junction aneurysm," Neurologia MedicoChirurgica, vol. 52, no. 6, pp. 430-434, 2012. 


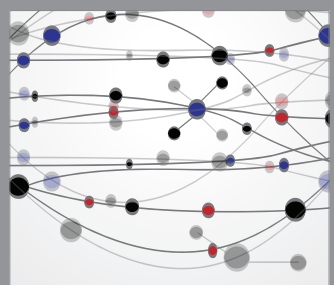

The Scientific World Journal
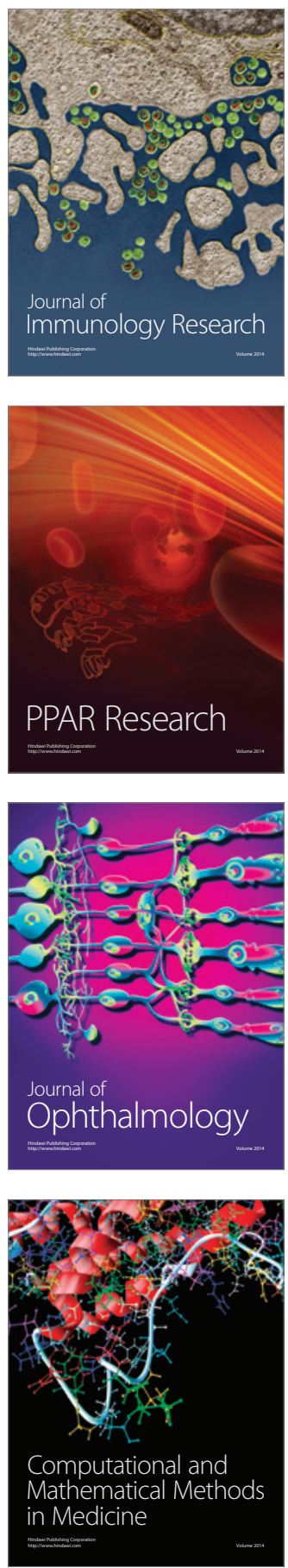

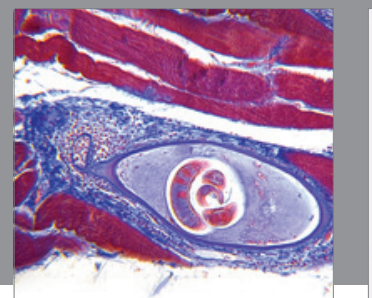

Gastroenterology

Research and Practice
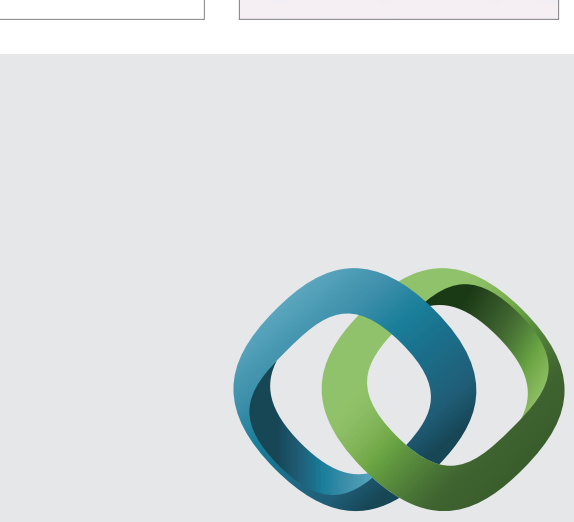

\section{Hindawi}

Submit your manuscripts at

http://www.hindawi.com
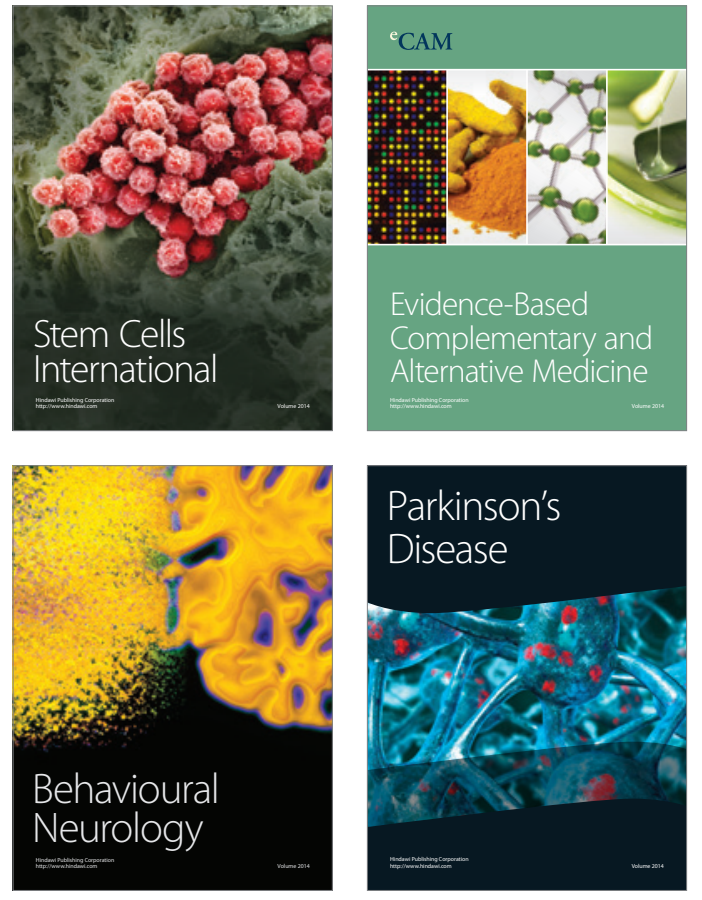
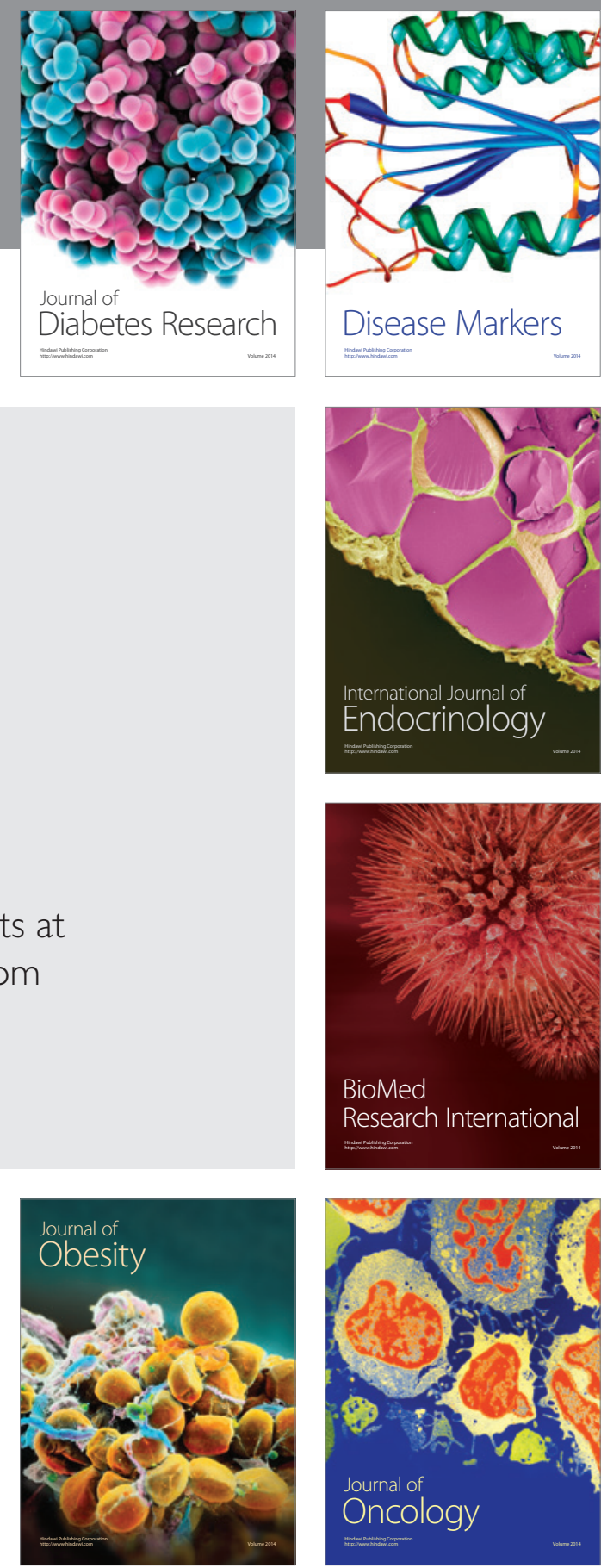

Disease Markers
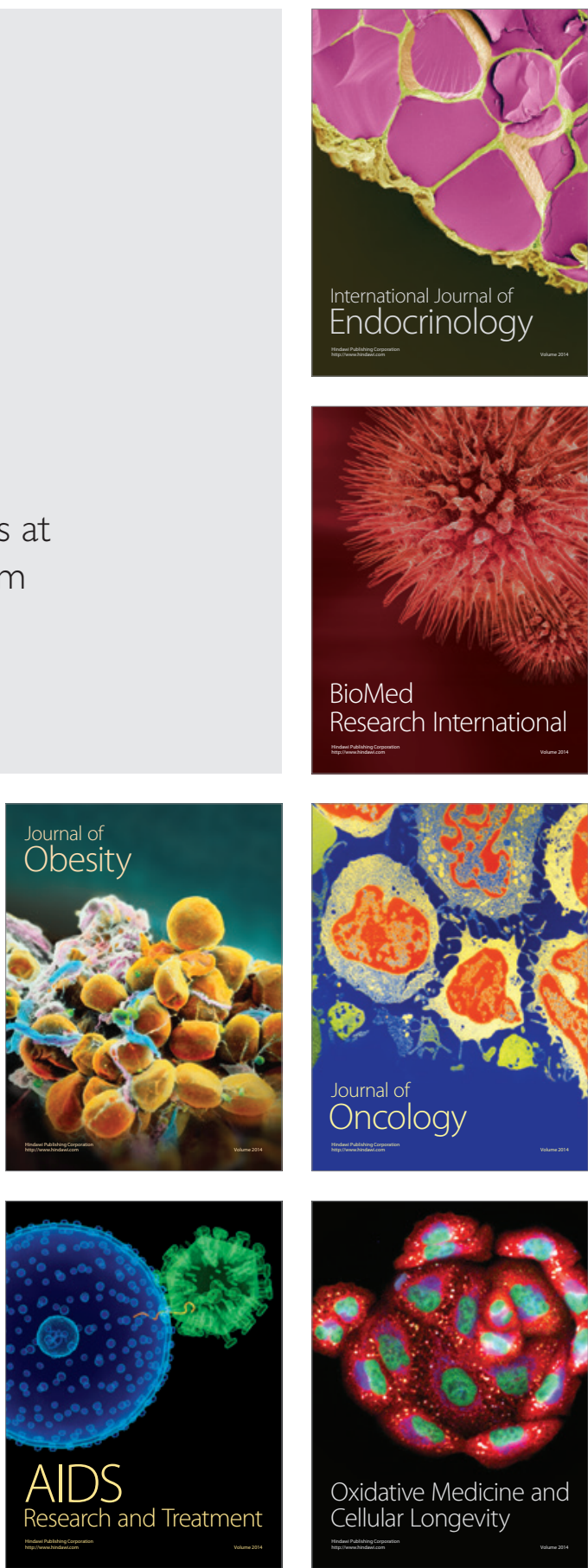